$\begin{array}{ll}\text { Abstracta Iranica } & \begin{array}{l}\text { Abstracta Iranica } \\ \text { Revue bibliographique pour le domaine irano-aryen }\end{array} \\ & \text { Volume } \mathbf{2 7} \mid \mathbf{2 0 0 6} \\ & \text { Comptes rendus des publications de } \mathbf{2 0 0 4}\end{array}$

\title{
Transeuphratène, 28, (2004)
}

\section{Astrid Nunn}

\section{(2) OpenEdition}

\section{Journals}

Édition électronique

URL : http://journals.openedition.org/abstractairanica/5785

DOI : 10.4000/abstractairanica.5785

ISSN : 1961-960X

Éditeur :

CNRS (UMR 7528 Mondes iraniens et indiens), Éditions de l'IFRI

Édition imprimée

Date de publication : 15 mai 2006

ISSN : 0240-8910

\section{Référence électronique}

Astrid Nunn, «Transeuphratène, 28, (2004) », Abstracta Iranica [En ligne], Volume 27 | 2006, document 109, mis en ligne le 02 janvier 2007, consulté le 25 septembre 2020. URL : http://

journals.openedition.org/abstractairanica/5785; DOI : https://doi.org/10.4000/abstractairanica.5785

Ce document a été généré automatiquement le 25 septembre 2020

Tous droits réservés 


\title{
Transeuphratène, 28, (2004)
}

\author{
Astrid Nunn
}

1 Ce volume est le premier d'une série de trois où paraîtront les Actes du VIe Colloque international sur la Transeuphratène à l'époque perse: Pouvoirs, sociétés et religions qui a eu lieu du 6 au 8 novembre 2003 à Paris. Une fois de plus les «fondateurs» de la recherche sur la Phénicie achéménide, J. Elayi, J. Sapin et J. Briend ont rassemblé des chercheurs dont les disciplines extrêmement différentes reflètent l'approche polyvalente de ce thème. Les biblistes P. Abadie et J. Asurmendi traitent d'Esdras (c.r. $\mathrm{n}^{\text {os }} 55$ et 59), D. Bondi et B. Gosse de la société à Jérusalem (c.r. $n^{\text {os }} 61$ et 76 ), C. Arnould-Béhar de l'archéologie à Jérusalem (c.r. n58), A. Lemaire de l'Idumée (c.r. n87), Z. U. Ma'oz de Sidon (c.r. $n^{\circ} 93$ ), S. F. Bondi des Phéniciens et des Puniques (c.r. $\left.n^{\circ} 62\right)$, H. Nutkowicz des textes d'Éléphantine (c.r. n98), A. Destrooper de numismatique chypriote (c.r. n67), A. Nunn de terres cuites syriennes (c.r. ${ }^{\circ}{ }^{97}$ ) et enfin J. Jany de lois sassanides (c.r. $\left.n^{\circ} 83\right)$.

\section{INDEX}

Thèmes : 3.2.1. Elam

\section{AUTEURS}

ASTRID NUNN

Université de Munich 